\title{
KEPENARIAN TOKOH KEN DEDES DALAM KEN DEDES: THE SOLILOQUY KARYA MATHEUS WASI BANTOLO
}

\author{
Dea Putri Komala Sari \\ Institut Seni Indonesia (ISI) Surakarta \\ Jalan Ki Hadjar Dewantara No.19, Kentingan, Jebres, Surakarta 57126 \\ Matheus Wasi Bantolo \\ Institut Seni Indonesia (ISI) Surakarta
}

\begin{abstract}
The fullness of the work of Ken Dedes: The Soliloquy is an interpretation of a female character named Ken Dedes from the work of Arok The Godfather's Soliloquy of Matheus Wasi Bantolo. The study discusses the process and forms of fullness from Ken Dedes: the Soliloquy. To describe this, several concepts were used: In reviewing the fullness of matter using the concept of Alma Hawkins, to describe the form of opera using the concept of Peter Sellars and Matheus Wasi Bantolo, while describing the form of In the works using the Suzane K Langer concept is reinforced by the concept of dance analysis according to Janet Adshead. Writing and reviewing using qualitative methods that are descriptive interpretative, with the observation process participant action research. Results of this study showed that the fullness process conducted based on the process of exploration, improvisation and composition as a stage of the work of the fullness of Ken Dedes: the Soliloquy. The present form of presentation is a new interpretation of the character Ken Dedes in the work of Arok The Godfather's Soliloquy. The fullness of Ken Dedes: The Soliloquy has a form of dish with an opera concept that uses five dancers who each have dual roles as dancers and musicians. Many movements adopted the movement of Javanese traditions in Surakarta style by combining the elements of Latin dance motion in them. It is based on the thought of choreographer to elaborate on The character Ken Dedes as a woman in the past with female figures in The Godfather film and female figures at present. The fullness of the work of Ken Dedes: The Soliloquy has a perspective on how Ken Dedes as women with the various problems faced can be aligned with women today.
\end{abstract}

Keywords: fullness, character Ken Dedes, Opera.

\section{PENDAHULUAN}

Kepenarian dipahami sebagai kemampuan ketubuhan penari dalam menginterpretasi suatu karya tari dan mempersiapkan ketubuhannya untuk menyajikan karya tari tersebut (Bantolo, Wawancara 12 Oktober 2018).

Penelitian ini membahas kemampuan penari dalam menyajikan karya berbentuk opera. Sehingga kepenarian dalam mewujudkan hal tersebut di atas dibutuhkan suatu kemampuan penari sesuai dengan bentuk tari yang disajikan. Seorang penari dapat diartikan sebagai seseorang yang menterjemahkan keinginan koreografer melalui karya tarinya sehingga menjadi objektif. Hal ini sebagaimana Sri Rochana Widyastutieningrum memberikan 
istilah mengobjektifkan subjektivitas karya koreografer (Widyastutieningrum, 2011: 83$84)$.

Penari dalam suatu karya berbentuk opera memerlukan suatu proses dan kemampuan untuk mendukung unsurunsur yang ada di dalamnya. Kemampuan penari dalam karya berbentuk opera adalah mengolah dan merajut suara berlagu dan menyatu dalam gerak-gerak tari (Bantolo, Wawancara 12 Oktober).

Ken Dedes: the Soliloquy adalah salah satu karya dari Wasi Bantolo yang merupakan akademisi Institut Seni Indonesia (ISI) Surakarta. Karya tersebut diciptakan tahun 2019 dengan latar belakang karya menggambil cerita dari kisah perjalanan Ken Dedes. Karya yang diciptakan oleh Wasi Bantolo tersebut merupakan karya yang menggunakan elemen-elemen tari tradisi Jawa gaya Surakarta, dan kemudian dikombinasikan dengan unsur-unsur gerak tari Latin. Wasi menciptakan sebuah konsep tradisi secara bentuk garap tetapi dalam isian materi geraknya dikombinasikan dengan materi gerak tari Latin, serta memasukan musik dan syair bernuansa Latin. Hal ini menunjukan karya tersebut sebagai suatu karya tari kontemporer sebagaimana dalam perkembangan tari kontemporer yang ditandai adanya dialog antara kreatifitas individu koreografer dan tradisi dari koreografer tersebut, serta interaksi budaya dengan tradisi lainnya (Bantolo, 2016: 89).

Pembahasan kepenarian dalam karya Ken Dedes: the Soliloquy menitikberatkan pada kepenarian tokoh Ken Dedes. Kepenarian tokoh Ken Dedes adalah suatu sajian kemampuan ketubuhan dalam mewujudkan tokoh Ken Dedes. Ken Dedes dalam karya Arok The Godfather s Soliloquy adalah bagian dari ungkapan jiwa Ken Arok tentang sosok perempuan yang menjadi idamannya sebagaimana kerinduannya atas sosok ibu yang tidak pernah dia rasakan (Wasi Bantolo, Wawancara 12 Oktober 2018). Karya kepenarian tokoh Ken Dedes akan diwujudkan dalam sosok yang menceritakan kehidupannya dan keterkaitannya dengan Ken Arok.

Ken Dedes merupakan sosok wanita Nareswari dibalik kemulyaan sekaligus kehancuran terhadap peristiwa-peristiwa yang terjadi pada Ken Arok. Ken Dedes mempunyai peranan yang sangat penting dalam perjalanan Ken Arok sebagai seorang wanita yang juga memiliki kuasa dalam hidupnya. Hal ini ditunjukan dengan banyaknya peristiwa- perisiwa penting yang terjadi atas kecerdasan dan kuasa diri yang dimilikinya.

Tercapainya kualitas seorang penari diperlukan sebuah pengalaman yang dapat mendukung karya kepenarian tersebut. Pengalaman berproses yang telah dilalui dan keterlibatan dalam beberapa karya koreografer yang menciptakan pengalaman empiris dalam memori pikir dan memori tubuh. Pengalaman tersebut mempengaruhi pola berproses untuk menciptakan dan menarikan sebuah karya.

Proses yang dilalui mampu membawa tubuh seorang penari menjelajahi ruang imajinasi dan mengekspresikan sebuahide. Adapun beberapa pengalaman berproses yang dilalui, antara lain sebagai penari karya Tandhing Gendhing The Mothers dalam acara Festival Kesenian Indonesia 2018, Kayungyun Acapella dalam acara Art Jog 2018, Bedhayan dalam acara Opening Hari Wayang Dunia, Bedhaya Ela-ela pada 
ujian Pembawaan, mendukung beberapa ujian Tugas Akhir, proses bersama komunitas Wan yabala, Proses karya tari Amartya, dan sebagai penari tokoh Ken Dedes dalam ujian mata kuliah Koreografi dengan bentuk opera tari.

\section{PEMBAHASAN}

\section{Pengkarakteran Tokoh Ken Dedes dalam} Ken Dedes: the Soliloquy

Soliloquy memiliki makna yang berarti gumaman, tentang sesuatu yang dipikirkan namun tidak ada yang mendengarkan. Istilah Soliloquy sendiri sebenarnya berangkat dari dunia teater, ketika sebuah karya lebih mengedepankan seorang aktor dalam menceritakan persoalan dirinya sendiri. Karya ini mengungkapkan seorang perempuan yang bercerita tentang kehidupannya dan segala peristiwa yang dia alami bersama lelaki yang dicintainya. Interpretasi tokoh Ken Dedes dalam karya Ken Dedes: the Soliloquy terkait dengan kata kunci dalam karya ini yaitu Soliloquy.

Ken Dedes: the Soliloquy merupakan bentuk karya opera. Hal ini ditunjukkan dengan adanya perpaduan tari, drama, dan musik dalam karya tersebut. Karya ini juga bisa digolongkan sebagai opera tari dimana dialog pada setiap penari dinyanyikan dengan menggunakan musik orkestra.

Karakter Perempuan dalam Ken Dedes: The Soliloquy

a. Karakter Tokoh Ken Dedes dalam Novel Sejarah

Ken Dedes merupakan tokoh perempuan paling eksentrik dalam catatan sejarah kerajaan Singasari. Eksentriksitas yang dimiliki Ken Dedes merupakan satu ruh kultural. Darah Brahmana yang mengalir dari Mpu Purwa, membuatnya tumbuh menjadi perempuan rupawan, terdidik serta berkarakter.

Ken Dedes dalam novel sejarah Arok Dedes karya Pramoedya Ananta Toer mengalami transformasi dari seorang brahmani menjadi pramesywari yang disembah diseluruh Pakuwan Tumapel. Dia menyimpan sebuah ambisi besar, tidak akan membiarkan dirinya mati sia-sia dalam keputusasaan atau tercekik aura kedengkian yang begitu pekat di Pakuwuan. Dedes menyadari bahwa dia bukan Dewi Shinta yang tahan menderita, yang tidak bersedia memberikan diri dan hatinya demi kesetiaan serta penantiannya. Dedes lebih memilih menyebut dirinya Banowati bagi Hyang Durga, yang harus menjadi pramesywari demi mengembalikan cakrawati Hyang Durga di jagad Pramuditha.

Karakter kepahlawanan dalam buku Arok Dedes secara mutlak diberikan kepada Ken Arok dan karakter antagonis disematkan kepada tokoh Tunggul Ametung, maka Dedes berada diantara kedua wilayah tersebut, artinya tidak hitam dan tidak putih. Ken Dedes merupakan pribadi yang utuh dan kompleks. Dia sangat membenci Tunggul Ametung bahkan menghinakan segala laku dan perkataan suaminya tersebut, namun Dedes tidak bisa memungkiri bahwa dia mulai menikmati kekuasaan sebagai pramesywari dalam Pakuwuan Tumapel. Dedes mengutuk hari ketika dirinya diculik, namun perlahan mensyukuri detik perpisahan antara Dedes anak brahmana tiada arti menjadi Ken Dedes sang Pramesywari. Selama di Pakuwan hatinya rusuh dan di penuhi duka cita, Dedes selalu memandang rendah Tunggul Ametung 
karena meskipun seorang akuwu namun bermuasal dari kasta sudra dan tidak lebih tinggi dari dirinya yang berdarah Brahmana. Namun di lain pihak Dedes justu mencintai Ken Arok yang juga berdarah sudra.

b. Karakter Ken Dedes sebagai Perempuan dalam karya Ken Dedes: the Soliloquy

Tokoh Ken Dedes pada karya ini tidak sekedar digambarkan seperti dalam ceritacerita maupun pertunjukan teater yang menceritakan sosok permaisuri di kerajaan Singasari pada masa lampau, namun lebih menggambarkan tokoh Ken Dedes sebagai perempuan dengan berbagai persoalan dan peristiwa yang dialaminya.

Ken Dedes tidak digambarkan sebagai sesuatu yang diam atau bersifat pasif dan hanya menonton pertarungan dari jauh sambil berharap-harap cemas, tetapi Ken Dedes menjadi sosok yang turun tangan dalam kancah pertarungan, bahkan menyusun taktik dengan caranya sendiri. Permasalahan cinta dalam karya Ken Dedes: the Soliloquy, mengangkat keresahan dan kegelisahan hati seorang perempuan dalam pengabdian. Keadaan itu dijalaninya dengan keterpaksaan selayaknya yang telah dialami seorang Ken Dedes.

Perempuan dengan segala keistimewaannya hingga membuat Tunggul Ametung yaitu seorang pemimpin kerajaan Tumapel sangat ingin menjadikannya istri. Dikisahkan bahwa pernikahan Tunggul Ametung dengan Ken Dedes terjadi didasari oleh paksaan dari Tunggul Ametung. Dalam perjalanannya Ken Dedes harus menerima takdirnya menjalani hidup dengan laki-laki yang tidak dicintainya, mendampingi dan melayani sang Akuwu dengan setengah hati. Namun dari pernikahannya bersama
Tunggul Ametung mereka dikaruniai seorang putra yang bernama Anusapati. Diceritakan pada saat Anusapati masih didalam kandungan, Tunggul Ametung terbunuh oleh pengawal kepercayaannya sendiri yaitu Ken Arok. Dalam rencana pembunuhan yang disengaja itu Ken Dedes pun mengetahui bahwa Ken Arok lah yang sudah membunuh suaminya dengan mengkambing hitamkan Kebo Ijo. Namun mengetahui hal itu Ken Dedes yang sudah jatuh cinta kepada Ken Arok membiarkannya begitu saja. Ken Arok pun berhasil menggantikan Tunggul Ametung sebagai Akuwu Tumapel dan menikah dengan Ken Dedes.

Perspektif seorang perempuan dalam menjalani sebuah kehidupan normal menjadi nilai utama untuk memunculkan karakter Ken Dedes, karakter ini sengaja dimunculkan untuk menampilkan sosok perempuan di masa kini, dimana perempuan menjadi simbol kekuatan dan tokoh yang berpengaruh dalam kehidupan masa kini. Sebagai seorang perempuan yang sanggup menjadi pemimpin, Ken Dedes menyimpan kelemahan-kelemahan yang sangat besar pengaruhnya di balik sebuah keputusan. Sisi realita dari kehidupan seorang pemimpin perempuan, yaitu pertemuan, jatuh cinta, keagungan, pengkhianatan, dan kekecewaan, tersebut kemudian menjadi sebuah ide pendukung gagasan untuk memunculkan karakter baru Ken Dedes dalam karya Ken Dedes: the Soliloquy.

c. Peran dan Representasi Perempuan dalam karya Ken Dedes; the Soliloquy

Peran perempuan sangat besar kaitannya dengan karya ini. Dapat dilihat 
sebagaimana perempuan menjadi gagasan utama dalam konsep yang dihadirkan pada karya tersebut. Peran Ken Dedes dengan semangat perlawanan terlihat jelas dalam novel Arok Dedes. Pram memberi ruang yang lebih bagi Ken Dedes untuk menampilkan kegetiran menghadapi nasib, kegelisahan serta karakternya yang begitu kuat. Namun apabila dilihat dari perkembangannya, lintasan historis manusia di dunia telah menempatkan perempuan dalam posisi tersubordinasi, termarginalisasi, teralienasi, dan terdominasi oleh kaum lakilaki. Secara statistik, kaum perempuan mendapatkan posisi kurang menguntungkan dalam berbagai aspek kehidupan. Relasi antara perempuan dan laki-laki sangat terbatas dalam kepentingan terbatas pula, seperti yang dikemukakan Sunur berikut.

Tokoh Ken Dedes yang merupakan salah satu gambaran dari perempuan yang berada pada posisi tersebut, sehingga dalam karya Ken Dedes: the Soliloquy peran perempuan menjadi pandangan utama dalam sajiannya. Representasi tokoh Ken Dedes dalam karya ini dihadirkan dalam kepenarian satu orang penari namun melibatkan penari lain untuk mengisi peran perempuan- perempuan lain yang ada dalam perjalanan peristiwa Ken Arok. Namun, pada dasarnya perempuan-perempuan serta Ken Dedes dalam segala permasalahannya merasakan sesuatu hal yang sama hingga kemudian penyelesaian pada diri sendiri menjadi pilihan terakhir.

Pemasalahan perempuan dalam karya Ken Dedes: The Soliloquy yang dihadirkan lewat syair-syair

Permasalahan seorang perempuan yang dihadirkan dalam karya Ken Dedes: the
Soliloquy merupakan gambaran peristiwaperistiwa yang sudah Ken Dedes alami pada kehidupan masa lalunya. Peristiwa tersebut yang kemudian diungkapkan melalui syairsyair lagu dalam karya tersebut.

Suatu keagungan seorang perempuan dan semangat seorang Ken Dedes yang diungkapkan melalui syair lagu Majesta Viesta pada bagian awal menjadi pembuka dalam karya Ken Dedes: the Soliloquy. Syair ini menjadi introduksi dimana kemunculan sosok Ken Dedes dihadirkan dalam karya tersebut.

Syair La Vida, mengungkapkan tentang sosok perempuan yang memiliki kehidupan panjang bersama seorang lelaki yang menginginkan berada pada kemenangan untuk jalan menuju surga. Dalam pandangannya sosok laki-laki tersebut hanya menginginkan suatu kekuasaan dan kemegahan dengan mendapatkan seorang perempuan berparas cantik. Laki-laki yang ketika itu menginginkan seorang perempuan sematamata untuk kepentingannya sendiri. Sampai kemudian melihat sosok laki-laki lain dengan penawarannya memberikan harapan cinta yang sesungguhnya.

Syair pada lagu Ismuning sampai dengan Sajodo Kambangan merupakan gambaran seorang perempuan yang sedang merasakan kedamaian pada dirinya setelah menemukan cinta. Perempuan dalam hal ini adalah Ken Dedes yang belum benar-benar mencintai seorang sosok yang akan menjadi suaminya.

Harapan tersebut hanya tinggal harapan karena yang Ken Dedes temui hanyalah kesepian dan merasa dirinya hadir untuk dimanfaatkan. Permasalahan ini dihadirkan dalam syair lagu Memanis. Pada 
lagu ini perempuan dihadapkan pada seorang laki-laki yang memiliki ambisi besar atas kekuasaan yang sudah di pada lagu memanis. Ternyata dia dihadapkan pada seorang lelaki yang memiliki ambisi atas kekuasaan yang sudah dimilikinya. Laki-laki tersebut mulai menemukan kebahagiaan-kebahagiaan lain seperti sebuah kemuliaan, kekayaan, dan wanitawanita lain dalam perjalanannya. Pada syair lagu Arus Monggang, perempuan hanya bisa melihat laki-laki tersebut mendapatkan kemuliaan yang dicita-citakannya. Bahkan ketika perempuan ingin menjadi bagian dari itu semua akan tetap hanya diindahkan dan disingkirkan oleh sosok laki-laki tersebut.

\section{Bentuk Sajian}

Janet Adshead menyebutkan bahwa ada beberapa komponen- komponen yang dapat diteliti dalam tari antara lain: penari, gerak, tata visual, dan elemen suara (1998: 22). Hal tersebut yang kemudian digunakan untuk menguraikan bentuk sajian tari Ken Dedes: the Soliloquy.

\section{Penari}

Penari merupakan elemen pokok dan utama dalam suatu pertunjukan tari. Penari adalah seseorang yang mampu menterjemahkan keinginan koreografer melalui suatu karya tari. Dalam hal ini penari juga dituntut untuk menguasai konsep mungguh serta mampu menjiwai tokoh yang dibawakan. Penari dapat menginterpretasikan peran yang akan dibawakan dengan pemahaman dari penari itu sendiri, sehingga sebuah hasil dari karakter yang muncul merupakan hasil dari interpretasi penari melalui pemahaman yang mereka tangkap (Adshead, 1998:62).

\section{Jumlah Penari}

Karya Ken Dedes: the Soliloquy ini disajikan oleh lima orang penari, yang terdiri dari tiga penari perempuan dan dua penari laki-laki, untuk melengkapi konsep pertunjukannya dihadirkan tiga pemusik yang dilibatkan secara langsung dengan menghadirkan mereka di atas panggung. Kehadiran mereka di atas panggung disesuaikan dengan konsep pertunjukan yang di tawarkan oleh koreografer.

\section{Gerak}

Gerak sebagai bentuk ekspresi gagasan, merupakan salah satu elemen penting untuk mewujudkan sebuah karya tari. Dalam proses penciptaan tari, seorang pencipta dapat mengambil pola gerak tradisi yang sudah ada kemudian dikembangkan menjadi bentuk-bentuk baru, maupun melalui proses eksplorasi mencari bentuk-bentuk gerak baru sebagai media penerjemah gagasan karya tari.

\section{Pola Gerak}

Gerak tari pada karya Ken Dedes: the Soliloquy menggunakan gerak tradisi Jawa yaitu gaya Surakarta yang dipadukan dengan materi gerak latin. Gerak-gerak tersebut dipilih sebagai pengaplikasian gagasan karya yang sudah ada. Seperti yang sudah dibahas sebelumnya pada proses penciptaan karya, terlebih dahulu di lakukan eksplorasi-eksplorasi dalam prosesnya untuk mendapatkan gerak yang terlihat sederhana namun indah. Selain itu, setiap gerak dalam karya ini merupakan ungkapan suasana serta ekspresi dari setiap adegan-adegan di dalamnya, sehingga diperlukan garis-garis tubuh yang lebih tajam agar isi pada setiap gerak yang dihadirkan dapat tersampaikan. 
Karya Ken Dedes: the Soliloquy menggunakan gerak tradisi Jawa seperti sekaran-sekaran anglir mendhung, manglung, lembehan, engkyek, dan pendapan. Adapun gerak lain seperti ngleyang, enjer, srisig, dan kengser yang digunakan oleh penari. Bentuk-bentuk jari yang digunakan adalah ngithing, nyempurit dan ngrayung. Untuk mempertebal karakter Ken Dedes dalam karya tersebut maka penari lebih memperluas volume gerak dan menggunakan polatan dengan jarak pandang yang lebih jauh.

\section{Tata Busana}

Penggunaan busana dalam pertunjukan tari dapat memperkuat sebuah karakter atau watak dalam sajian bentuk tari. Busana tidak semata-mata digunakan melainkan memiliki arti dan fungsi dalam penggunaannya. Bentuk busana yang dipilih dalam karya Ken Dedes: the Soliloquy mengambil konsep dari bentuk samparan yaitu salah satu cara berkain penari putri dengan menyisakan ujung jarik untuk media bantu visual. Adapun untuk karya ini samparan tidak dikenakan sebagai mana mestinya samparan melainkan ada variasi bentuk untuk mendukung pergerakan dari pada penari. Cara berkain yang digunakan dalam karya ini yaitu dengan menarik sisa kain bagian kanan ke arah dalam menuju luar sehingga membentuk seperti celana pada bagian belakang. Sebagai pelengkap dan untuk memadukan samparan tersebut kemudian di tambah mekak yang dililitkan seperti dodot berwarna abu-abu, ungu, dan biru bermotif sibori dengan perpaduan kain merah ditengah seperti ilatilatan. Perhiasan yang digunakan tidak terlalu banyak, yaitu hanya menggunakan kalung dan gelang ganitri sebagai pelengkap busana yang dikenakan. Penari laki-laki hanya menggunakan celana dengan motif serupa dengan penari putri dan telanjang dada, kemudian untuk pemusik menggunakan setelan Jas berwarna hitam untuk menguatkan konsep opera yang menjadi gagasan utama dalam karya ini. Warna merah menjadi warna dominan untuk konsep busana dalam karya Ken Dedes: the Soliloquy, hal ini dikarenakan merah dirasa warna paling mendukung untuk pengkarakteran seseorang yang berjiwa berani dan dinamis.

\section{Musik}

Musik merupakan unsur pendukung sajian dalam karya tari Ken Dedes: the Solilo$q u y$, secara menyeluruh telah mengalami penggarapan secara selektif. Hal ini terlihat dari rasa musikal yang secara padu dengan rasa dan suasana yang disajikan dalam karya tersebut. Musik dalam karya tari ini menggunakan dua elemen musikal dari dua kebudayaan yang berbeda, baik instrumen maupun konsep garapnya. Musik karawitan dalam kebudayaan Jawa berdialog dengan instrumen-instrumen musik dari kebudayaan Eropa tengah, atau akrab disebut musik barat. Adapun instrumen musik yang digunakan dalam karya tari ini antara lain: Siter laras slendro/pelog, Suling Jawa, Gitar akustik, Biola, Cello, dan Rebab. Selain itu garap musik pada karya ini adalah bagaimana vokal yang juga dikemas dari dua sumber budaya musik tersebut di atas, tembang-tembang berlaras slendro/ pelog berkomunikasi dengan sistem nada diatonis dari kebudayaan musik barat tanpa saling menghilangkan identitas musikal satu sama lain. 


\section{PENUTUP}

Kepenarian tokoh Ken Dedes dalam karya Ken Dedes: the Soliloquy merupakan hasil suatu proses ketubuhan dalam menyajikan karya kepenarian tokoh Ken Dedes. Karya ini adalah interpretasi dari karya Arok The Godfather's Soliloquy yang diciptakan pada tahun 2010. Karya ini diinspirasi dari salah seorang tokoh perempuan pada masa kerajaan Singasari bernama Ken Dedes yang mendampingi Raja pendiri wangsa yaitu Ken Arok dan perempuan yang mendampingi sosok Michael Corleone yang merupakan seorang putra mahkota sekaligus penerus sindikat kartel terkenal di Italia. Kompleksitas permasalahan yang dialami Ken Dedes kemudian coba dikaitkan dengan fenomena permasalahan faktual wanita pada umumnya saat ini, antara lain soal cinta, ambisius, kesetiaan, dan keikhlasan. Emosi dari setiap perasaan tersebut yang kemudian dihadirkan lewat estetika ketubuhan, musik, artistik pada karya Ken Dedes: The Soliloquy.

Penyajian karya kepenarian dalam bentuk opera menuntut kesatuan utuh kemampuan penari yang meliputi suara, gerak, tata visual, dan kemampuan penari. Karya ini menggunakan lima orang penari, yang terdiri dari tiga penari perempuan dan dua penari laki-laki, untuk melengkapi konsep pertunjukkannya dihadirkan tiga pemusik yang dilibatkan secara langsung dengan menghadirkan mereka di atas panggung. Gerak dan suara adalah penggabungan dari tari dan gamelan Jawa gaya Surakarta dengan tari dan musik Latin.

Proses penciptaan karya kepenarian Ken Dedes: the Soliloquy menghasilkan penemuan-penemuan kemampuan kepenarian seperti kemampuan gerak, kemampuan pengkarakteran, kemampuan vokal, kemapuan pemahaman busana, sampai dengan kemampuan pemahaman bentuk panggung.

\section{DAFTAR PUSTAKA}

Adshead, Janet. 1998. Dance Analysis Theory And Practice. London: Cecil Court.

Di Yanni, Robert. 2000. Fiction; An Introduction. New York: Mc Graw Hill.

Eriyanto, 2006. Analisis Wacana: Pengantar Analisi Teks Media. Yogyakarta: LKis Yogyakarta.

Fanani, Zaenal. 2003. Ken Arok: Cinta dan Takhta. Solo. Perbit Tiga Serangkai.

Gendhon Humardani. Gendhon Humardani Pemikiran dan Kritiknya. Surakarta: STSI-PRESS,1991.

Hawkins, Alma M. Mencipta Lewat Tari (Creating Throught Dance). Terj. Y. Sumandyo Hadi. Yogyakarta: STSIPRESS, 1991.

2003. Bergerak Menurut Kata Hati terj. Prof. Dr. I Wayan Dibia. Jakarta: Ford Fondation dan Masyarakat Seni Pertunjukan Indonesia.

Keraf, Gorys. 2004. Diksi dan Gaya Bahasa. Jakarta: PT Gramedia Pustaka Utama. 


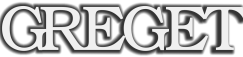

Maryono. 2010. Pragmatik Genre Tari Pasihan Gaya Surakarta. ISI Press Solo.

Matheus Wasi Bantolo. 2002. "Alusan Pada Tari Jawa". Tesis, Surakarta: ISI Surakarta.

Pramoedya Ananta T. 2006. Arok Dedes. Jakarta: Lentera Dipantara

Praja Dihasta Kuncari Putri. Kertas Kerja "Kepenarian Topeng dalam Karya Kayungyun". Surakarta. 2017.

Puzo, Mario. 1969. The Godfather. Jakarta: PT Gramedia Pustaka Utama.

Ranggah Radjasa. Legenda Arok Dedes. Jakarta, 2017.

Sellars, Peter. 2004. Exits and Entrances: On Opera dalam Contemporary Theatre Review. Nanyang Technologycal University.

Slamet. Garan Joged Sebuah Pemikiran Sunarno. Surakarta Press, 2014. Soedarsono. Pengantar Pengetahuan dan Komposisi Tari. Yogyakarta: Akademi Seni Tari Indonesia,1978.
Sri Devi Dyah Pitaloka, “ Tokoh Gendari dalam Karya Tari Topeng Opera Tandhing Gendhing: The Mothers Karya Wasi Bantolo". Laporan Tugas Akhir, 2018.

Sri Rochana Wiedyastutieningrum, Dwi Wahyudiarto. 2014. Pengantar Koreografi. Surakarta: ISI Press. . 2006. Tayub Di Blora Jawa Tengah Pertunjukan Ritual Kerakyatan. Surakarta: STSI Press.

Sunur, Effendi Kusuma. 2006. “Kekerasan Terhadap Perempuan Suatu Akibat Cara Pandang Lain," dalam Jurnal Filsafat Driyarkara, Edisi Th. XXVIII No. 3/2006, hlm. 6.

Suryawan, I. Ngurah. 2009. Bali Pascakolonial: Jejak Kekerasan dan Sikap Kajian Budaya. Yogyakarta. Kepel Press.

Suzanne K. Langer. Problematika Seni. Terj. Fx. Widaryanto. Bandung: ASTI. 1998.

Toer, Pramoedya Ananta. 2009. Arok Dedes. Jakarta: Lentera Dipantara. 